\title{
Uji Efek Imunomodulator VCO (Virgin Coconut Oil) Pada Tikus Jantan
}

\section{(Test of Immunomodulatory Effects from VCO (Virgin Coconut Oil) In Male Rats)}

\author{
Loraetta Brety Sebayang*, Ahmad Syukur Hasibuan \\ Program Studi Farmasi, Institut Kesehatan Medistra, Jl.Sudirman, Lubuk Pakam, Deli Serdang, \\ Sumatera Utara 20512 \\ *Email korespondensi: lorettabretysebayang@medistra.ac.id
}

(Article History: Received August 25, 2021; Revised Sept 17, 2021; Accepted Sept 20, 2021)

\begin{abstract}
ABSTRAK
Virgin coconut oil merupakan minyak kelapa murni.VCO mengandung Medium Chain Fatty Acid (MCFA) yang memiliki pengaruh dalam meningkatkan sistem imunitas. Penelitian ini bertujuan untuk menguji efek imunomodulator VCO terhadap aktivitas fagositosis dan nilai titer antibodi pada tikus jantan. Kelompok uji bersihan karbon dibagi menjadi 5 kelompok dengan masing-masing terdiri dari 5 tikus yaitu kelompok suspensi $\mathrm{CMC} \mathrm{Na} 0,5 \%$, Imboost dosis $30 \mathrm{mg} / \mathrm{kgBB}$, virgin coconut oil 5 $\mathrm{ml} / \mathrm{KgBB}, 10 \mathrm{ml} / \mathrm{KgBB}, 15 \mathrm{ml} / \mathrm{KgBB}$. Perlakuan diberikan sehari sekali selama tujuh hari dan hari ke delapan dilakukan uji imunomodulator dengan metode bersihan karbon. Kelompok perlakuan uji titer antibodi sama seperti di atas selain kontrol positif menggunakan levamisole dosis $25 \mathrm{mg} / \mathrm{kgBB}$ diberikan secara oral selama 14 hari. Hasil penelitian menunjukkan bahwa VCO $5 \mathrm{ml} / \mathrm{KgBB}, 10$ $\mathrm{ml} / \mathrm{KgBB}, 15 \mathrm{ml} / \mathrm{KgBB}$ meningkatkan aktivitas fagositosis sel makrofag dibandingkan dengan NaCMC $0,5 \%(P<0,05)$ dan berpengaruh secara signifikan meningkatkan pembentukan antibodi sel imun tikus jantan.
\end{abstract}

Kata Kunci: Virgin coconut oil; imunomodulator; fagositosis; titer antibodi

\begin{abstract}
Virgin coconut oil (VCO) is pure coconut oil. VCO contains Medium Chain Fatty Acid (MCFA) which has an influence increased immune system. This study was to determine the immunomodulatory effect of VCO on phagocytic activity and antibody titer values in male rats. The carbon clearance test group was divided into 5 groups with 5 rats each of $0.5 \%$ CMC Na suspension, Imboost dose of 30 $\mathrm{mg} / \mathrm{kgBW}$, Virgin coconut oil $5 \mathrm{ml} / \mathrm{KgBW}, 10 \mathrm{ml} / \mathrm{KgBW}, 15 \mathrm{ml} / \mathrm{KgBW}$. The treatment was given once a day for seven days, on the eight day immunomodulatory test was performed use carbon clearance method. The antibody titer test treatment group was same, except for the positive control, levamisole at a dose of $25 \mathrm{mg} / \mathrm{kgBW}$ orally for 14 days. The results showed that $V C O 5 \mathrm{ml} / \mathrm{KgBB}, 10 \mathrm{ml} / \mathrm{KgBB}, 15$ $\mathrm{ml} / \mathrm{KgBB}$ significantly increased macrophage cell phagocytic activity compared to $0.5 \% \mathrm{Na-CMC}$ $(P<0.05)$ and could increase cell antibody formation immunity of male mice significantly.

Keywords: Virgin coconut oil; immunomodulator; phagocytosis; antibody titer
\end{abstract}

\section{PENDAHULUAN}

Perubahan zaman yang modern seperti saat ini berdampak pada gaya hidup masyarakat. Salah satu perubahan yang terlihat pada masyarakat yakni Gaya hidup yang cepat dan instan. Hal tersebut berpengaruh terhadap kualitas makanan yang dikonsumsi, kurangnya aktivitas fisik, paparan polusi udara dan stres yang menyebabkan imunitas tubuh terus menurun. Dalam kondisi ini, mikroorganisme seperti bakteri, virus, jamur, dan parasit dapat dengan mudah menyerang dan menyerang pertahanan tubuh sehingga menyebabkan berbagai infeksi, penyakit degeneratif, dan penuaan dini (Azizah 2017).

Untuk melindungi tubuh pada proses pertahanan, homeostasis dan pengawasan, dibutuhkan respon imun agar tubuh terlindungi dari pengaruh lingkungan yang menjadi sumber penyakit, sistem imun bekerja dengan beberapa mekanisme pertahanan yaitu saluran pernafasan, saluran cerna dan kulit hingga ke jaringan. Sistem imun juga bekerja mengeliminasi sel-sel mati dalam tubuh dan memperbaiki jaringan 
serta menghancurkan sel-sel abnormal yang bermutasi agar tidak menjadi ganas (Togatorop 2021). Sistem imun terdiri dari sistem imun spesifik (imunadaptif) dan sistem imun non spesifik (innate atau natural immunity). Sistem imun spesifik diperankan oleh limfosit B dan limfosit $\mathrm{T}$ (Syahrana 2017).

Menurut penelitian sebelumnya (Silalahi et al. 2016), telah melakukan pengujian peningkatan ketahanan mencit dan penyembuhan luka dengan pemberian VCO. VCO meningkatkan sistem imun terhadap infeksi bakteri dilihat dari proliferasi limfosit. Minyak esensial dari asam lemak meningkatkan kapasitas imun dengan memperbaiki metabolisme dan meningkatkan SOD. VCO mengandung MCFA yang dilaporkan dapat mencegah komplikasi pada pasien diabetes (Sheela et al. 2017); mengurangi risiko penyakit kardiovaskular dan kanker (Narayanankutty et al. 2018); meningkatkan HDL (High Density Lipoprotein) (Chinwong et al. 2017).

Minyak kelapa murni (VCO) telah terbukti memiliki beberapa manfaat nutrisi dan terapeutik (Babu 2014). Secara tradisional, minyak kelapa yang dibuat dengan metode pengolahan kering telah menjadi bagian dari makanan dan pengobatan Asia Tenggara karena kaya akan kandungan asam lemak rantai sedang. Sebaliknya, VCO diproses secara basah yang menghasilkan retensi komponen bioaktif, termasuk tokoferol, tokotrienol, dan polifenol. Senyawa bioaktif ini diperkirakan bertanggung jawab atas aktivitas antioksidan; antiinflamasi, anti-piretik, analgesik, dan hipolipidemik VCO (Fernando 2015). Selain senyawa bioaktif ini, monolaurin, produk gliserol dan asam laurat, diketahui memodulasi proses inflamasi dan juga memiliki sifat imunomodulator dan antimikroba. Sifat antioksidan dari VCO telah ditemukan relatif lebih baik daripada minyak kelapa tradisional karena kandungan polifenol bioaktif, tokoferol, sterol, dan squalene yang lebih tinggi dalam VCO (Wallace 2018;
Intahphuak 2010). Penelitian ini bertujuan untuk menguji efek imunomodulator VCO terhadap aktivitas fagositosis dan nilai titer antibodi pada tikus jantan.

\section{METODE}

Penelitian ini menggunakan metode eksperimental dengan tikus jantan sebagai hewan percobaan untuk melihat efek imunomodulator VCO (Virgin Coconut Oil) menggunakan metode uji bersihan karbon dan titer antibodi. Peralatan yang digunakan yaitu alat-alat gelas laboratorium, aluminium foil, centrifuge, lumpang, stamper, sonde (Terumo), neraca listrik (Vibra), neraca hewan, spuit $1 \mathrm{ml}$ (Terumo), oral sonde, seperangkat alat bedah, microtube, microtitration plate, micropipette (Socorex), dan spektrofotometer $U V$-visible sedangkan untuk bahan-bahan yang digunakan yaitu VCO, karboksil metil selulosa (CMC-Na), Natrium sitrat (Na-sitrat), $\mathrm{NaCl}, \mathrm{Na}_{2} \mathrm{HPO}_{4}$, Nutrient Broth (NB), asam asetat $1 \%$, suspensi imboost, suspensi levamisole, tinta cina, dan tikus jantan.

\section{Pembuatan Suspensi Imboost}

Dimasukkan 2 tablet imboost (setiap tablet mengandung $250 \mathrm{mg}$ zat aktif) ke dalam lumping dan digerus. Ditambahkan secukupnya suspensi CMC-Na $\quad 0,5 \%$ dihomogenkan. Suspensi dalam tentukur 100 ml dituangkan sampai batas tanda kemudian dikocok ringan hingga homogen.

\section{Pembuatan Suspensi Karbon}

Diambil 1,6 $\mathrm{ml}$ tinta cina lalu dimasukkan ke dalam lumpang, ditambahkan suspensi CMC-Na 0,5\% yang dilarutkan dalam larutan fisiologis $\mathrm{NaCl}$ $0,9 \%$ secukupnya dan dihomogenkan, lalu dimasukkan ke dalam labu tentukur $10 \mathrm{ml}$, cukupkan dengan suspensi CMC-Na 0,5\% yang dilarutkan dalam larutan fisiologis Nacl 0,9\% sampai batas tanda (Faradilla 2014).

\section{Pembuatan Suspensi CMC Na 0,5\%}

Mortar yang berisi $20 \mathrm{ml}$ air mendidih ditaburkan 0,5 g CMC Na 0,5\%. Didiamkan 
selama 15 menit, kemudian digerus sampai diperoleh suspensi jernih, dan ditambahkan sedikit air, disiapkan labu ukur $100 \mathrm{ml}$ dimasukkan suspensi lalu dicukupkan dengan air sampai batas tanda.

\section{Uji Bersihan Karbon (Carbon Clearence)}

Absorbansi bersihan karbon diukur menggunakan spektrofotometer dengan panjang gelombang $640,5 \mathrm{~nm}$.

Kelompok I : Suspensi CMC-Na 0,5\%

Kelompok II: Suspensi Imboost dengan dosis $22,5 \mathrm{mg} / \mathrm{KgBB}$

Kelompok III: VCO dosis $5 \mathrm{ml} / \mathrm{KgBB}$

Kelompok IV: VCO dosis $10 \mathrm{ml} / \mathrm{KgBB}$

Kelompok V : VCO dosis $15 \mathrm{ml} / \mathrm{KgBB}$

Setiap kelompok perlakuan diberikan suspensi secara oral satu kali sehari selama tujuh hari berturut-turut pada setiap kelompok perlakuan. Dilakukan pengambilan darah dan penyuntikan suspensi karbon pada hari ke delapan. Darah diambil melalui ujung ekor tikus dengan memotong ujung ekor tikus lalu ditampung ke dalam tube yang diisi Na-sitrat, diambil $25 \mu \mathrm{l}$ darah lalu ditambahkan $4 \mathrm{ml}$ asam asetat $1 \%$. Sampel divorteks agar sel darah merah lisis, darah pertama digunakan sebagai blanko (menit 0), kemudian sebanyak $0,1 \quad \mathrm{ml}$ suspensi karbon disuntikkan melalui pembuluh darah di ekor secara intravena, dilakukan pengambilan darah pada menit ke-5, 10, 15, dan 20 setelah penyuntikan karbon, ditampung ke dalam tube berisi Na-sitrat, masing-masing ditambahkan $4 \mathrm{ml}$ asam asetat $1 \%$ ke dalam darah yang diambil sebanyak $25 \mu \mathrm{l}$ lalu divortex. Absorbansi diukur menggunakan spektrofotometer $U V$-Visible pada panjang gelombang $640,5 \mathrm{~nm}$.

Tikus dikorbankan setelah 12 jam sejak pengambilan sampel darah, lalu organ hati dan limfa tikus diambil, ditimbang dan dicatat beratnya (Aldi et al. 2013). Konstanta kecepatan eliminasi karbon (K), indeks fagositosis $(\alpha)$ dan indeks stimulasi dihitung menggunakan rumus:

$$
\begin{aligned}
(\mathrm{K})= & \frac{\log \mathrm{A}(\mathrm{n})-\log \mathrm{A}(\mathrm{n}-1)}{\mathrm{T}(\mathrm{n}-1)-\mathrm{t}(\mathrm{n})} \\
& \frac{\log O D 5-\log O D 20}{t 2-t 1}
\end{aligned}
$$

Indeks Fagositosis

$$
\begin{aligned}
& =\frac{K^{1 / 3} \times \text { Berat Hewan }}{\text { Berat hati }+ \text { berat limfa }} \\
& \text { Indeks Stimulasi } \\
& =\frac{\text { Indeks Fagositosis Kelompok Uji }}{\text { Indeks Fagositosis Kelompok Kontrol }}
\end{aligned}
$$

Keterangan:

OD5 : absorbansi padamenit ke-5

OD20 : absorbansi pada menit ke -20

T1 : waktu pertama pengambilan darah

T2 : waktu terakhir pengambilan darah

Indeks fagositosis dan indeks stimulasi dari tiap kelompok uji dibandingkan dengan kelompok kontrol (Kala et al. 2015).

\section{Pengukuran Jumlah Total Leukosit dan Diferensial Leukosit}

Pemeriksaan jumlah sel leukosit darah dan diferensiasi sel leukosit yang digunakan adalah darah pada prosedur metode carbon clearance. Setelah hari ke-8, sebanyak $1 \mathrm{ml}$ darah diambil dimasukkan ke dalam tube yang telah berisi Na-sitrat dan diperiksa jumlah total leukosit dan diferensial sel leukosit di Laboratorium Institut Kesehatan Medistra Lubuk-Pakam.

\section{Pembuatan Phosphate Buffered Saline (PBS)}

Disiapkan terlebih dahulu pembuatan larutan A yaitu larutan $\mathrm{Na}_{2} \mathrm{HPO}_{4}$ 1,3 g/l dan $\mathrm{NaCl} 8,3 \mathrm{~g} / \mathrm{l}$ dan pembuatan larutan $\mathrm{B}$ yaitu larutan $\mathrm{Na}_{2} \mathrm{HPO}_{4}$ 1,42 g/l dan $\mathrm{NaCl} 8,5 \mathrm{~g} / \mathrm{l}$. Selanjutnya $280 \mathrm{ml}$ larutan A ditambahkan pada $720 \mathrm{~mL}$ larutan B untuk mendapatkan PBS dengan pH 7,2 (Indrisari 2017).

\section{Penyiapan Suspensi Levamisole}

Tablet levamisole diambil sampelnya dengan metode isobarik dan digiling menjadi bubuk halus minimal 10 tablet. 
Bubuk tersebut kemudian ditimbang agar sesuai dengan sekitar $50 \mathrm{mg}$ levamisol. Suspensi levamisole dibuat dengan menimbang serbuk levamisole lalu dimasukan ke dalam lumpang dan digerus, tambahkan secukupnya suspensi CMC Na $0,5 \%$ gerus hingga homogen dimasukkan ke dalam labu takar $25 \mathrm{ml}$ dan ditambahkan suspensi CMC Na 0,5\% hingga garis tanda.

\section{Pembuatan Antigen Bakteri Stapylococcus aureus}

Diinkubasi bakteri S. aureus dalam $9 \mathrm{ml}$ medium NB selama 1 x 24 jam. Diambil sebanyak $1 \mathrm{ml}$ untuk dilakukan proses perhitungan bakteri dengan menggunakan spektrofotometry sampai mendapat konsentrasi bakteri $10^{8} \mathrm{sel} / \mathrm{ml}$. Dilakukan sentrifugasi dengan kecepatan $10.000 \mathrm{rpm}$ selama 10 menit. Pelet yang diperoleh selanjutnya disuspensikan dengan $1 \mathrm{ml}$ PBS. Suspensi tersebut selanjutnya diinjeksikan pada hewan coba secara intraperitoneal dengan volume 100 mikroliter $(100 \mu \mathrm{l})$ atau $0,1 \mathrm{ml}$.

\section{Uji Titer Antibodi}

Efek imunomodulator VCO ditentukan menggunakan uji titer antibodi dengan cara melihat aglutinas. Penentuan dosis dilakukan berdasarkan data orientasi yang sudah dilakukan sebelumnya. Sebanyak 25 ekor tikus dibagi menjadi 5 kelompok dengan pembagian sebagai berikut:

Kelompok I : suspensi CMC Na 0,5\% (b/v) sebagai kontrol negatif

Kelompok II: suspensi levamisole dengan dosis $25 \mathrm{mg} / \mathrm{kg}$ BB sebagai kontrol positif

Kelompok III: VCO dosis $5 \mathrm{ml} / \mathrm{kgBB}$

Kelompok IV: VCO dosis $10 \mathrm{ml} / \mathrm{kgBB}$

Kelompok V : VCO dosis $15 \mathrm{ml} / \mathrm{kgBB}$

Semua perlakuan diberikan satu kali sehari mulai hari ke 0 sampai 14 hari. Tiap kelompok hewan percobaan diinjeksikan dengan $0,1 \mathrm{ml}$ secara intraperitoneal Suspensi bakteri $S$. aureus $10^{8} \mathrm{sel} / \mathrm{ml}$ dalam PBS pada hari ke-4 sebagai antigen. Pada hari ke-14, sampel darah masing-masing tikus diambil melalui pembuluh darah vena di bagian ekor. Caranya adalah dengan menggunakan pisau untuk memperbaiki ujung ekor tikus dan menyedot darah keluar ke dalam jarum suntik $1 \mathrm{ml}$, sampel darah kemudian ditempatkan dalam mikrotubulus dan disentrifugasi pada $1900 \mathrm{rpm}$ selama 10 menit pada suhu $4^{\circ} \mathrm{C}$ menggunakan sentrifuga untuk mengumpulkan serum. Titer antibodi ditentukan oleh hemostasis. $25 \mu \mathrm{l}$ serum diteteskan ke dalam sumur microtitration plate 96 lubang, ditambahkan PBS dan suspensi bakteri $S$. aureus dengan volume yang sama dan diencerkan dua kali lipat $(1: 2 ; 1: 4 ; 1: 8 ; 1: 16 ; 1: 32 ; 1: 64 ; 1: 128$; $1: 256 ; 1: 512 ; 1: 1024 ; 1: 2048 ; 1: 4096)$ kemudian diinkubasi pada suhu $37^{\circ} \mathrm{C}$ selama 1 jam dan diamati hemaglutinasi secara visual. Pengenceran terakhir dihitung sebagai nilai titer antibody, dimana secara visual antibodi masih terdeteksi melalui hemaglutinasi yang ditransformasikan dengan [2log(titer)+1] (Marbun 2017).

\section{HASIL DAN PEMBAHASAN}

Laju bersihan karbon merupakan suatu metode yang digunakan untuk mengukur aktivitas fagositosis pada tikus. Hasil uji bersihan karbon dalam darah tikus dapat dilihat pada Tabel 1 .

Pada menit ke-5, 10, 15 dan 20 terdapat perbedaan signifikan antara $\mathrm{CMC} \mathrm{Na} 0,5 \%$ dengan Imboost $30 \mathrm{mg} / \mathrm{kgBB}$. Tidak terdapat perbedaan signifikan antara $\mathrm{CMC}$ $\mathrm{Na} 0,5 \%$ dengan VCO $5 \mathrm{ml}$ dan $10 \mathrm{ml} / \mathrm{kgBB}$. Tidak terdapat perbedaan signifikan antara imboost $30 \mathrm{mg} / \mathrm{kgBB}$ dan VCO $15 \mathrm{ml} / \mathrm{kgBB}$. Hal ini sesuai dengan penelitian sebelumnya yaitu semakin tinggi nilai konstanta bersihan karbon maka kecepatan bersihan karbon juga semakin cepat sehingga dapat disimpulkan semakin cepat proses fagositosis oleh sel fagositik (Aldi et al. 2013).

Nilai rata-rata indeks fagositosis menunjukan aktivitas fagosistosis sel-sel fagositik terhadap partikel karbon sebagai antingen. Indeks fagositosis setelah pemberian VCO yang dapat dilihat pada Gambar 1. 
Tabel 1. Uji bersihan karbon dalam darah tikus

\begin{tabular}{llccc}
\hline $\begin{array}{c}\text { Kelompok } \\
\text { Perlakuan }\end{array}$ & Menit 5 & Menit 10 & Menit 15 & Menit 20 \\
\hline Na-CMC0,5\% & 0,2 & 0,142 & 0,140 & 0,117 \\
IMBOOST 30 mg/kgbb & 0,105 & 0,084 & 0,079 & 0,006 \\
VCO 5 ml/kg bb & 0,146 & 0,100 & 0,128 & 0,091 \\
VCO 10 ml/kg bb & 0,135 & 0,129 & 0,112 & 0,092 \\
VCO 15 ml/kg bb & 0,122 & 0,113 & 0,264 & 0,086 \\
\hline
\end{tabular}

Keterangan :

$\mathrm{a}=\mathrm{p}<0,05$, signifikan dengan kelompok CMC Na 0,5\%

$\mathrm{b}=\mathrm{p}<0,05$, signifikan dengan kelompok imboost

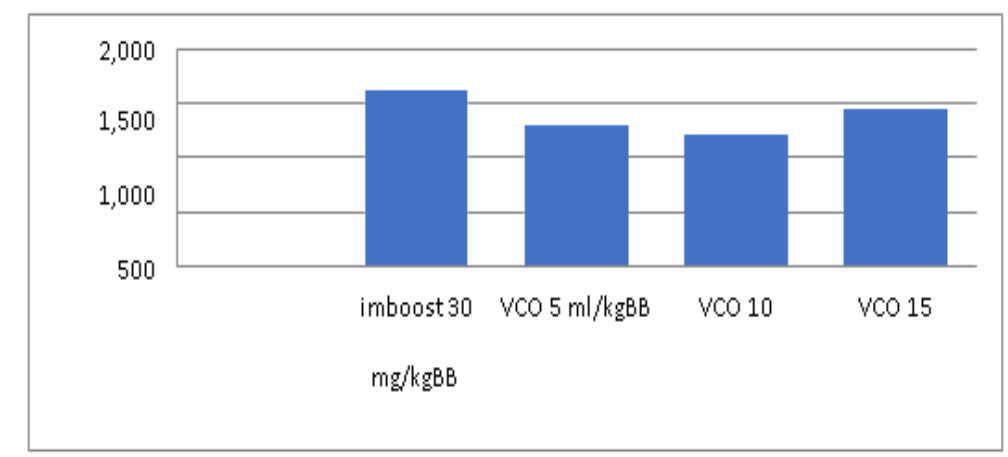

Gambar 1. Indeks stimulasi fagositosis.

Pada Gambar 1 menunjukkan bahwa pada masing-masing kelompok VCO 5 $\mathrm{ml} / \mathrm{kgBB}$ dengan indeks stimulasi 1,290 , VCO $10 \mathrm{ml} / \mathrm{kgBB}$ dengan indeks stimulasi 1,209, menunjukkan bahwa VCO merupakan zat yang bersifat imunostimulan, kekuatan VCO volume $15 \mathrm{ml} / \mathrm{kgBB}$ hampir sama dengan kontrol positif imboost. Indeks stimulasi volume $\mathrm{VCO} 5, \quad 10,15$ menunjukkan adanya keterkaitan peningkatan dosis dengan nilai indeks stimulasi, dimana semakin tinggi peningkatan volume dan indeks stimulasi, semakin tinggi dosis maka nilai indeks stimulasi yang didapat juga meningkat. Imunosupresan secara tidak langsung mendekati nilai indeks stimulasi kontrol positif (imboost $30 \mathrm{mg} / \mathrm{kgBB}$ ). Hal ini disebabkan karena imboost adalah terapi penunjang yang digunakan untuk stimulasi sistem imun.

Berdasarkan nilai rata-rata indeks fagositosis tiap volume VCO indeks fagosistosis yang paling baik terlihat pada VCO dosis $15 \mathrm{mg} / \mathrm{BB}$ namun indeks fagosistosis yang didapat masih dibawah indeks fagosistosis suspensi imboost 30 mg/BB. Hal ini menunjukan keterkaitan peningkatan dosis dengan nilai indeks fagositosis, dimana semakin besar peningkatan dosis maka nilai indeks fagositik juga meningkat. Semakin meningkat indeks fagositik pada uji bersihan karbon menunjukkan adanya peningkatan aktivitas fagositositik dari makrofag dan peningkatan imunitas non spesifik.

Titer antibodi ditentukan dengan metode hemaglutinasi, nilai titer antibodi diukur pada hari ke-14 setelah pemberian perlakuan masing-masing kelompok. Hal ini bertujuan untuk mengetahui respon imun humoral terhadap S. aureus. Pengenceran terakhir dihitung sebagai nilai titer antibodi dimana secara visual antibodi masih terdeteksi melalui hemaglutinasi. Peningkatan nilai titer antibodi dibuktikan dengan adanya peningkatan titer antibodi tikus yang memberi tanda kepekaan sel $\mathrm{T}$ dan sel $\mathrm{B}$ terkait dengan produksi antibodi, hasil uji titer antibodi dapat dilihat pada Tabel 2 dan Gambar 2. 
Tabel 2. Nilai titer antibodi

\begin{tabular}{llcc}
\hline \multirow{2}{*}{ NO } & \multicolumn{1}{c}{ Perlakuan } & \multicolumn{2}{c}{ Nilai Titer Antibodi } \\
\cline { 3 - 4 } & & Titer Antibodi & [2Log(titer $)+1$ \\
\hline 1 & Na-CMC 0,5 \% & 8 & 2,80 \\
2 & Suspensi Levamisole $25 \mathrm{mg} / \mathrm{KgBB}$ & 256 & 5,81 \\
3 & VCO 5 ml/KgBB & 16 & 3,40 \\
4 & VCO 10 ml/KgBB & 51,2 & 4,41 \\
5 & VCO 15 ml/KgBB & 128 & 5,21 \\
\hline
\end{tabular}

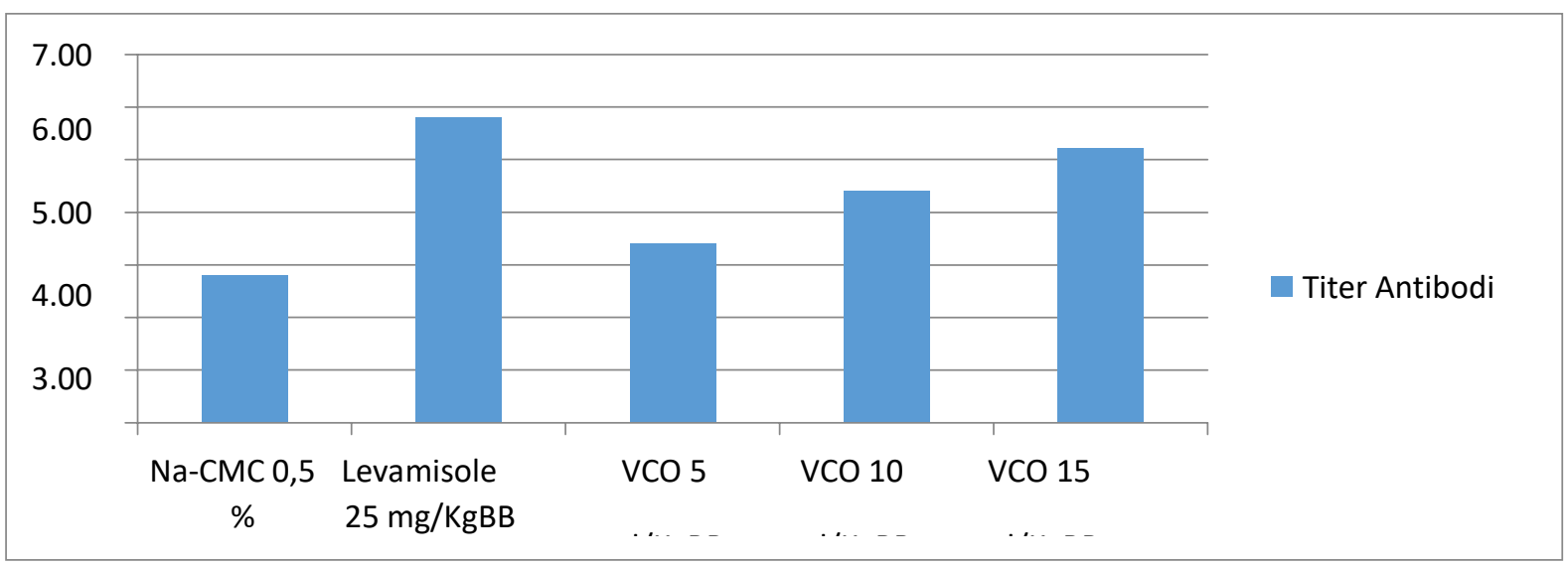

Gambar 2. Nilai titer antibodi pada tikus putih jantan.

Pada Gambar 2 terlihat bahwa VCO 15 $\mathrm{ml} / \mathrm{KgBB}$ lebih besar dibandingkan dengan $\mathrm{Na}-\mathrm{CMC} \quad 0,5 \%$ sebagai kontrol negatif. Pemberian VCO $15 \mathrm{ml} / \mathrm{KgBB}$ menunjukan peningkatan titer antibodi sebesar 5,21 $\mu$, namun nilai ini tidak lebih besar dengan suspensi levamisole dosis $25 \mathrm{mg} / \mathrm{KgBB}$ yang bernilai $5,81 \mu \mathrm{l}$. Nilai titer antibodi VCO $15 \mathrm{ml} / \mathrm{KgBB}$ senilai 5,21 $\mu$ l lebihbesar dibandingkan dengan VCO $5 \mathrm{ml} / \mathrm{KgBB}$ dan VCO $10 \mathrm{ml} / \mathrm{KgBB}$ bernilai 3,40; 4,41( $\mu \mathrm{l})$.

Untuk melihat ada atau tidaknya perbedaan terhadap kelompok hewan percobaan dilakukan analisis uji MannWhitney terhadap nilai titer antibodi. Hasil uji Mann-Whitney menunjukan adanya perbedaan signifikan antara kelompok perlakuan terhadap titer antibodi sel imun tikus jantan dengan nilai signifikan $(P<0,05)$. Berdasarkan uji statistik yang dilakukan menunjukan bahwa nilai titer antibodi tikus jantan kelompok perlakuan levamisole $25 \mathrm{mg} / \mathrm{KgBB}$, VCO $5 \mathrm{ml} / \mathrm{KgBB}$, VCO $10 \mathrm{ml} / \mathrm{KgBB}$, VCO $15 \mathrm{ml} / \mathrm{KgBB}$ berbeda signifikan dengan Na-CMC.
Peningkatan nilai titer antibodi dibuktikan dengan adanya peningkatan titer antibodi tikus yang memberi tanda kepekaan sel $\mathrm{T}$ dan sel B terkait dengan produksi antibodi.

Reaksi sekunder terjadi karena adanya interaksi antara antigen dengan antibodi yang berupa aglutinasi karena partikelpartikel kecil antigen yang tidak larut, dimana apabila antigen dan anti serum spesifik menyatu maka akan mengendap sebagai gumpalan yang besar, karena umumnya antibodi memiliki beberapa reseptor pengikat antigen yang akan bereaksi dengan molekul antigen lain mengikat salah satu molekul antibodi.

Jika rasio antara antigen dan antibodi berjumlah seimbang maka akan terjadia reaksi aglutinasi yang akan membentuk zona ekuivalen, dengan dukungan dari suhu tinggi $\left(37-56^{\circ} \mathrm{C}\right)$ dan gerakan yang menimbulkan peningkatan kontak antigen dan antibodi serta terjadinya pengumpulan gumpalan memerlukan garam-garam akibat PBS yang digunakan (Suriani 2019). 


\section{KESIMPULAN}

Berdasarkan hasil penelitian, dapat disimpulkan bahwa VCO memiliki efek immunomodulator terhadap peningkatan fagositosis dibandingkan dengan kontrol CMC $\mathrm{Na} 0,5 \%$, VCO $15 \mathrm{ml} / \mathrm{kgBB}$ memberikan efek meningkatkan aktivitas fagosistosis lebih kuat di bandingkan dengan VCO $5 \mathrm{ml}$ dan $10 \mathrm{ml} / \mathrm{kgBB}$. VCO 15 $\mathrm{ml} / \mathrm{kgBB}$ memberikan efek yang hampir sama dengan kontrol positif imboost. Pemberian virgin coconut oil dapat meningkatkan titer antibodi sel imun pada tikus jantan yang diinduksi bakteri Staphylococcous aureus dibandingkan dengan Na-CMC 0,5\% dengan dosis VCO $15 \mathrm{ml} / \mathrm{KgBB}$.

\section{UCAPAN TERIMA KASIH}

Penulis mengucapkan terimakasih kepada Kementerian Pendidikan, Kebudayaan, Riset, dan Teknologi, Direktorat Jendral Pendidikan Tinggi atas bantuan biaya pada skema hibah Penelitian Dosen Pemula (PDP); juga ucapan terimakasih kepada Bapak Rektor Institut Kesehatan Medistra Lubuk Pakam atas pemberian izin menggunakan fasilitas laboratorium yang sangat memadai untuk melakukan penelitian ini.

\section{DAFTAR PUSTAKA}

Aldi Y, Rasyadi Y, Handayani D (2014) Aktivitas Imunomodulator dari Ekstrak Etanol Meniran (Phyllianthus niruri Linn.) terhadap Ayam Broiler. Jurnal Sains Farmasi \& Klinis, 1(1), 20-26.

Azizah M, Wiraningsih W, Sari ER (2017)

Efek Imunomodulator Ekstrak Etanol

Kulit Buah Nanas (Ananas comosus L. Merr) terhadap Mencit Putih Jantan dengan Metode Bersihan Karbon (Carbon Clearance). Indonesian Journal of Applied Sciences.7(2).

Babu AS, Veluswamy SK, Arena R, Guazzi M, Lavie CJ (2014) Virgin coconut oil and its potential cardioprotective effects. Postgrad Med.126:76-83.

Bratawidjaja KG, Rengganis I (2014) Imunologi Dasar. Jakarta: Badan
Penerbit Fakultas Ilmu Kedokteran Universitas Indonesia.

Chinwong S, Chinwong D, Mangklabruks A (2017) Daily consumption of virgin coconut oil increases high-density lipoprotein cholesterol levels in healthy volunteers: A randomized crossover trial. Evidence-Based Complement Altern Med. 2017:1-8.

Fernando WM, Martins IJ, Goozee KG, Brennan CS, Jayasena V, Martins RN (2015) The role of dietary coconut for the prevention and treatment of Alzheimer's disease: potential mechanisms of action. Br J Nutr.114:114.

Indrisari M, Habibie H, Rahimah S (2017) Uji efek ekstrak etanol daun jarak pagar (Jatropha curcas L.) terhadap titer imunoglobulin $\mathrm{m}$ (igm) dan imunoglobulin $\mathrm{g}$ (IgG) pada tikus putih jantan (Rattus norvegicus). Jurnal farmasi UIN Alauddin Makassar, 5(4), 244-250.

Intahphuak S, Khonsung $\mathrm{P}$, Panthong $\mathrm{A}$ (2010) Anti-inflammatory, analgesic, and antipyretic activities of virgin coconut oil. Pharm Biol.48:151-7.

Kala C, Alin SS, Khan NA (2015) Immununostimulatory Potential of $\mathrm{N}$ Butanolic Fraction of Hydrialcoholic Extract of Costus Specious Koen. Rhizome. International Journal of Pharmacy and Pharmaceutical Sciences 6(7).

Makare N, Bodhankar S, Rangari V (2001) Immunomodulatory activity of alcoholic extract of Mangifera indica L. in mice. Journal of ethnopharmacology, 78(2-3), 133-137.

Marbun RAT (2017) Uji Efek Imunomodulator Ekstrak Etanol Herba Binara (Artemisia vulgaris L.) pada Tikus Jantan. Tesis. Medan: Fakultas Farmasi Universitas Sumatera Utara.

Narayanankutty A, Illam SP, Raghavamenon AC (2018) Health impacts of different edible oils prepared from coconut (Cocos nucifera): A 
comprehensive review. Trends Food Sci Technol. 80:1-7.

Silalahi J, Rosidah, Putra EDL, Satria D (2016) Hypoglycemic effect of hydrolyzed palm kermel oil in rats. Der Pharma Chemica, 8(20).

Sheela DL, Nazeem PA, Narayanankutty A, Shylaja RM, Davis SP, James P, Valsalan R, Devassy Babu T, Raghavamenon AC (2017) Coconut phytocompounds inhibits polyol pathway enzymes: Implication in prevention of microvascular diabetic complications. Prostaglandins, Leukot Essent Fat Acids. 127:20-24

Suriani (2019) Pengaruh Pemberian Ekstrak Etanol Rimpang Temu Hitam (Curcuma aeruginosa) Terhadap Peningkatan
Imunoglobulin G (Igg) Pada Tikus Putih Jantan. Jurnal herbal indonesia. 26859343.

Syahrana NA, Akrom A, Darmawan E (2017). Efek Serbuk Bunga Rosella Merah (Hibiscus sabdariffa L.) terhadap Ekspresi IL-10 pada Sukarelawan Sehat. Jurnal Farmasi Dan Ilmu Kefarmasian Indonesia, 4(1), 1-5.

Togatorop LB, Mawarti H, Saputra BA, Elon Y, Malinti E, Manalu NV, Faridah U (2021) Keperawatan Sistem Imun dan Hematologi. Yayasan Kita Menulis. Hal. 13,14 .

Wallace TC (2018) Health effects of coconut oil-a narrative review of current evidence. J Am Coll Nutr 5:1-11. 